Proc. Indian Acad. Sci. (Chem. Sci.), Vol. 98, No. 3, March 1987, pp. 165-169.

(C) Printed in India

\title{
Solvent extraction of metals using LIX26 extractant
}

\author{
G N RAO* and V RAMESH \\ Chemistry Department, Indian Institute of Technology, New Delhi 110016 , India
}

MS received 26 May 1986; revised 12 November 1986

\begin{abstract}
Solvent extraction of some selected metals from an aqueous buffered soluticn by LIX26 extractant has been studied. The $\mathrm{pH}_{1 / 2}$ values (at which $50 \%$ of metal ion is extracted) for extracting different metals by $1 \mathrm{v} / \mathrm{v} \%$ LIX26 extractant in methyl isobutyl ketone have been obtained. The order of extraction of metals by LIX26 extractant as a function of $\mathrm{pH}_{1 / 2}$ value is $\mathrm{Pd}$ (II) $<\mathrm{Cu}$ (II) $<\mathrm{Sb}$ (III) $<\mathrm{Fe}$ (II) $<\mathrm{Co}$ (II) $<\mathrm{Zn}$ (II) $<\mathrm{Ni}$ (II) $<\mathrm{Pb}$ (II) $<\mathrm{Mn}$ (II) $<\mathrm{Cd}$ (II).
\end{abstract}

Keywords. LIX26 extractant; $\mathrm{pH}_{1 / 2}$ values; hydrometallurgy.

\section{Introduction}

The major breakthrough in solvent extraction studies is the development of reagents known as chelating extractants (Ashbrook 1975). Among these extractants, compounds marketed under the trade name "LIX" reagents (Liquid Ion Exchange Reagent) by Henkel Corporation have assumed great importance in the hydrometallurgy of copper (Burkin 1983). These chelating extractants efiect efficient and economical separation of copper from virtually all other metals in solution under a wide range of conditions. Very little information is available on the extraction of metals other than copper using LIX extractants. In the present paper, extraction of copper(II), antimony(III), zinc(II), cadmium(II), cobalt(II), nickel(II), manganese(II), palladium(II), lead(II), iron(II), and rhodium(III) with LIX26 extractant has been investigated. Such a study would be helpful in providing basic information required for hydrometallurgical separations and in the development of new analytical methods.

\section{Experimental}

\subsection{Materials}

LIX26; HL (containing substituted oxine in kerosene) was kindly supplied by Henkel Corporation, USA. The $\mathrm{pH}$ of the aqueous phase was maintained by using mixtures of potassium chloride-hydrochloric acid for $\mathrm{pH} 1-3$, sodium acetate-acetic acid for $\mathrm{pH} \mathrm{4-6,} \mathrm{ammonium} \mathrm{chloride-ammonia} \mathrm{for} \mathrm{pH} \mathrm{8-10,} \mathrm{and} \mathrm{ammonium}$ acetate-ammonia for $\mathrm{pH} \mathrm{6-8.} \mathrm{A} \mathrm{constant} \mathrm{ionic} \mathrm{strength} \mathrm{in} \mathrm{the} \mathrm{aqueous} \mathrm{phase} \mathrm{was}$ maintained by using potassium nitrate solution. Potassium chloride was used to

\footnotetext{
* To whom all correspondence should be addressed.
} 
maintain ionic strength where hydrochloric acid was used. Analytical reagent grade methyl isobutyl ketone was used without further purification.

\subsection{Extraction procedure}

Ten millilitres of an aqueous layer containing an aliquot of metal solution, $5 \mathrm{ml}$ of buffer solution and $1 \mathrm{ml}$ of $1 \mathrm{M}$ potassium nitrate solution was equilibrated with $10 \mathrm{ml}$ of organic layer containing $1 \mathrm{v} / \mathrm{v} \%$ LIX26 in methyl isobutyl ketone (MIBK). The mixture, in a stoppered bottle, was shaken in a wrist-action mechanical shaker for a period sufficient for the attainment of equilibrium at $35 \pm 1^{\circ} \mathrm{C}$. After equilibriation, $\mathrm{pH}$ of the aqueous phase was measured by an expanded scale $\mathrm{pH}$ meter (ECIL, India). In the case of extraction from more acidic solutions, hydrochloric acid solution of different molarities was used for attaining the desired concentration of acid in the aqueous phase. The concentration of metal in the aqueous layer was then measured by an SP 191 Pye Unicam Atomic absorption spectrophotometer.

\section{Results and discussion}

The extraction of a metal ion with a chelating ligand having a replaceable hydrogen ion may be represented by the following equation (Marcus and Kertes 1969).

$$
\mathrm{M}_{\mathrm{aq}}^{n+}+n \mathrm{HL}_{\text {org }} \rightleftharpoons \mathrm{ML}_{n, \text { org }}+n \mathrm{H}_{\mathrm{aq}}^{+} \text {, }
$$

where $\mathrm{HL}=\mathrm{LIX} 26$ extractant.

The extraction constant (equilibrium constant) of this reaction is given by

$$
K_{\mathrm{ex}}=\mathrm{D}\left[\mathrm{H}^{+}\right]_{\mathrm{aq}}^{n} /[\mathrm{HL}]_{\mathrm{org}}^{n},
$$

where distribution coefficient $D$ is equal to the ratio $\left[\mathrm{ML}_{n}\right]_{\mathrm{org}} /\left[\mathrm{M}^{n+}\right]_{\mathrm{aq}}$. Equation (2) may be rewritten in the logarithmic form

$$
\log K_{\text {ex }}=\log D-n \mathrm{pH}-n \log [\mathrm{HL}]_{\text {org }},
$$

Since the LIX26 extractant was supplied to us in a diluted form, the concentration of the extractant was taken on a $v / v \%$ basis. At a fixed concentration of the extraction the equilibrium constant ( $K_{\mathrm{ex}}$ ) is proportional to $\mathrm{pH}_{1 / 2}$ values. The trend in $K_{\text {ex }}$ values is known by knowing the trend in $\mathrm{pH}_{1 / 2}$ values even though the absolute concentration of extractant is not known. LIX reagents used as extractants in commercial solvent extraction operations have, of necessity, to be produced on a large scale and do not have the purity of analytical reagents. It is not advisable (Ashbrook and Ritcey 1984) to do the initial work with refined or purified material in acquiring accurate data and then pilot the process using the commercially available material. In such studies impurities in reagents could render the work useless, since the extraction characteristics could be quite different using a pure material.

The data on the extraction of metals by LIX26 $1 \mathrm{v} / \mathrm{v} \%$ in MIBK as a function of $\mathrm{pH}_{1 / 2}$ values are given in table 1 . This agrees partly with the extraction data reported by Stary (1968) for 0.01 M oxine-chloroform solutions as given in table 1. Gentry and Sherrington (1950) also report an order of extraction of metals by oxine 
Table 1. Extraction data of some metals using $1 \mathrm{v} / \mathrm{v} \%$ LIX26 extractant in MIBK.

\begin{tabular}{|c|c|c|c|c|}
\hline Metal & $\begin{array}{l}\mathrm{pH}_{1 / 2}(50 \% \\
\text { extraction) }\end{array}$ & $\begin{array}{c}\text { pH for } \\
\text { complete } \\
\text { extraction }\end{array}$ & $\begin{array}{c}\text { Shaking } \\
\text { (min) }\end{array}$ & $\begin{array}{c}\mathrm{pH}_{1 / 2} 0.01 \mathrm{M} \\
\text { oxine in } \\
\mathrm{CHCl}_{3}{ }^{+}\end{array}$ \\
\hline $\operatorname{Mn}(\mathrm{II})$ & 6.75 & $\geqslant 7.9$ & 30 & $6 \cdot 66$ \\
\hline $\operatorname{Co}(I I)$ & $5 \cdot 00$ & $6 \cdot 7$ & 30 & $5 \cdot 08$ \\
\hline $\mathrm{Ni}(\mathrm{II})$ & $6 \cdot 15$ & $\geqslant 7.8$ & 30 & $3 \cdot 16$ \\
\hline $\mathrm{Cd}(\mathrm{II})$ & 6.95 & $\geqslant 8.6$ & 60 & 6.65 \\
\hline $\mathrm{Zn}(\mathrm{II})$ & $5 \cdot 40$ & $\geqslant 6.7$ & 30 & $5 \cdot 20$ \\
\hline $\mathrm{Cu}(\mathrm{II})$ & $\begin{array}{l}\text { Complete } \\
\text { extraction } \\
\text { in the } \mathrm{pH} \\
\text { range } 1.5-9\end{array}$ & & 5 & 1.77 \\
\hline $\mathrm{Pb}(\mathrm{II})$ & $6 \cdot 40$ & $\geqslant 8.5$ & 30 & $6 \cdot 04$ \\
\hline $\mathrm{Sb}$ (III) & $<1.5$ & $1 \cdot 5$ & 30 & - \\
\hline $\operatorname{Rh}($ III) & $\begin{array}{l}\text { only } 25 \% \\
\text { extraction }\end{array}$ & & 120 & - \\
\hline $\operatorname{Fe}(\mathrm{II})^{*}$ & $3 \cdot 8$ & $\geqslant 5 \cdot 0$ & 60 & - \\
\hline $\operatorname{Pd}(\mathrm{II})$ & $<1$ & - & 30 & $<0$ \\
\hline
\end{tabular}

* Chloroform as solvent; ${ }^{\dagger}$ Stary (1968)

as a function of $\mathrm{pH}_{1 / 2}$ values. It seems most likely that the extraction of metals by LIX26 extractant will generally follow that for metal oxinates. Since LIX26 resembles oxine in its extractive properties towards metals, it seems reasonable to suppose that similarities exist in their properties. There is also good agreement between extraction studies with LIX26 and Kelex 100 extractants. LIX26 possesses a $K_{D R}$ of 3 orders of magnitude larger and a rather small $K_{a}$ value than does oxine (Bag and Freiser 1982). Hence LIX26 offers an opportunity to study the mechanisms of metal extraction in acidic system not possible with oxine because of its low hydrophobicity as compared to LIX26 extractant.

The pH isotherms of LIX26 extractant with these selected metals are shown in figure 1. The order of extraction of metals by LIX26 extractant as a function of $\mathrm{pH}_{1 / 2}$ values is as follows:

$\mathrm{Pd}($ II $)<\mathrm{Cu}$ (II) $<\mathrm{Sb}$ (III) $<\mathrm{Fe}$ (II) $<\mathrm{Co}$ (II) $<\mathrm{Zn}$ (II) $<\mathrm{Ni}$ (II) $<\mathrm{Pb}$ (II) $<\mathrm{Mn}(\mathrm{II})<\mathrm{Cd}(\mathrm{II})$.

Except for Ni(II) and Cd(II) all the extraction data for LIX26 systems agree well with oxine systems (Stary 1968). Cadmium(II) forms hydrated complexes with oxine $\left(\mathrm{CdL}_{2} \mathrm{HL}\right)$ and with Kelex 100 forms complexes of the type $\mathrm{CdL}_{2}$ (Lakshmanan et al 1974). Since hydrated compiexes are better extracted into oxygenated solvents, cadmium extraction with LIX26 is effected at higher pH values as compared to oxine.

The order of extraction of metals by Kelex 100 as a function of $\mathrm{pH}_{1 / 2}$ value has been given as (Ma and Freiser 1984; Zhu and Freiser 1983):

$$
\mathrm{Pd}(\mathrm{II})<\mathrm{Cu}(\mathrm{II})<\mathrm{Ni}(\mathrm{II}) \text {. }
$$

The extraction behaviour of these selected metals by LIX26 extractant can be briefly summarised as follows: 


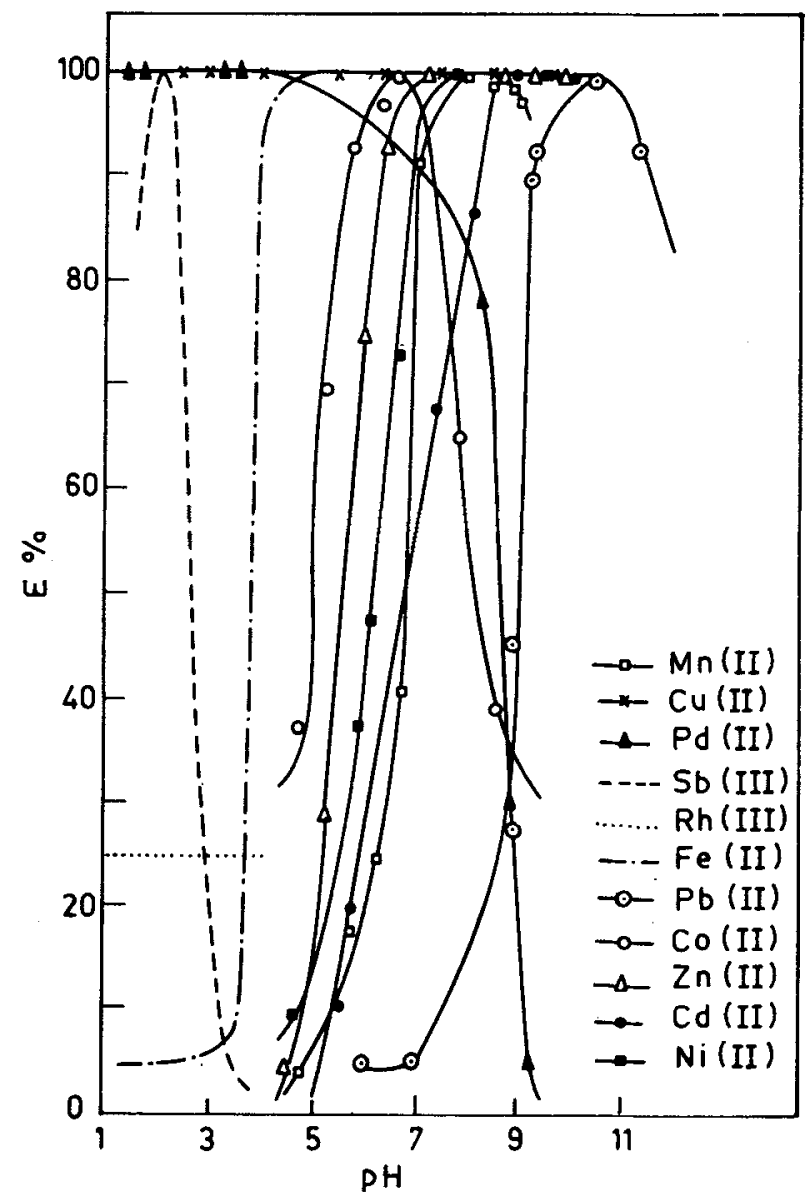

Figure 1. The pH isotherms of some selected metals using $1 \% \mathrm{v} / \mathrm{v}$ LIX26 extractant in MIBK. In case of $\mathrm{Pb}(\mathrm{II})$ the $\mathrm{X}$-axis has been shifted by $2.0 \mathrm{pH}$ units towards the + ve direction.

(i) Copper(II), antimony(III) and palladium(II) are extracted from acidic solutions. Antimony(III) gets extracted around pH 9 (Sandell 1959) with oxine, whereas with LIX26 an effective complete extraction is possible around pH 1.5. Palladium is extracted from highly acidic solutions thereby providing high selectivity in the recovery and purification of palladium. Effective separation of palladium is also achieved from nickel using this extractant.

(ii) Maximum extraction shown by rhodium(III) was only $25 \%$ above which no extraction was possible. At higher $\mathrm{pH}$ values extraction of cobalt(II) falls rapidly.

(iii) Complete extraction of copper(II), manganese(II), nickel(II), zinc(II), lead(II), cadmium(II) and iron(II) by using LIX26 extractant is around pH $\mathbf{8 \cdot 6}$, though copper(II) is also extractable from acidic solutions.

Thus a single extraction at $\mathrm{pH} 8.6$ from a dilute solution of metals into a smaller volume of the organic solvent will be a rapid and effective method of preconcentration of metals before atomic absorption spectrophotometric deter- 
mination (Cresser 1978). Since LIX26 is soluble to a good extent in many organic solvents, both microscale as well as macroscale operations are possible.

\section{References}

Ashbrook A W 1975 Coord. Chem. Rev. 16285

Ashbrook A W and Ritcey G M 1984 Solvent extraction principles and application to process metallurgy (Amsterdam: Elsevier) p. 87

Bag S T and Freiser H 1982 Anal. Chim. Acta 135319

Burkin A R 1983 Chem. Ind. 690

Cresser M S 1978 Solvent extraction in flame spectroscopic analysis (London: Butterworths) Chap. 2 Gentry C H R and Sherrington L G 1950 Analyst 7517

Lakshmanan V I, Lawson G J and Nyholm P S 1974 Intl. Solvent Extraction Conference, Lyon, France Ma $E$ and Freiser $H 1984$ Inorg. Chem. 233344

Marcus Y and Kertes A S 1969 Ion exchange and solvent extraction of metal complexes (London: Wiley Interscience) p. 509

Sandell E B 1959 Colorimetric determination of traces of metals (New York: Wiley Interscience) Chap. 6D

Stary J 1968 Anal. Chim. Acta 28132

Zhu L and Freiser H 1983 Anal. Chim. Acta 146237 